\title{
Bernadetta Manyś \\ (Poznań) \\ „WILEŃSKI ŚWIAT” ZYGMUNTA AUGUSTA W MONOGRAFII MIASTA PIÓRA JÓZEFA IGNACEGO KRASZEWSKIEGO
}

\footnotetext{
Abstract

The article aims to characterise the "Vilnius world" of king Zygmunt II August, as presented in a study of history of the Lithuanian capital written Józef Ignacy Kraszewski. The author attempts to show what kind of an image of Vilnius and its inhabitants in the times of the last Jagiellon was conveyed by Kraszewski in his description.
}

\section{Key words}

Vilnius, Zygmunt II August, Jagiellons, capital of the Grand Duchy of Lithuania 
Gdy 18 października 1529 r. dziewięcioletni Zygmunt August został wyniesiony w katedrze wileńskiej na tron wielkoksiążęcy, jego zapobiegawcza matka Bona nie zdawała sobie sprawy, że obrzęd ten na zawsze zwiąże jej syna z Litwą i Wilnem ${ }^{1}$. Anna Sucheni-Grabowska zauważyła, że trudno stwierdzić, jak często młody Jagiellon przybywał do Wilna, zanim osiadł w nim na dłużej w 1544 r. $^{2}$ Wiadomo jednak, że podczas wizyt w latach 1529-1544 miał on okazję dobrze poznać gród Giedymina ${ }^{3}$.

Niniejszy artykuł ma na celu scharakteryzowanie „wileńskiego świata” ostatniego z Jagiellonów przedstawionego w dziejach litewskiej stolicy pióra Józefa Ignacego Kraszewskiego ${ }^{4}$. Historia miasta wydana została w czterech

${ }^{1}$ J.I. Kraszewski, Wilno od początków jego do roku 1750, 1, Wilno 1840, s. 217; E. Gołębiowski, Zygmunt August. Żywot ostatniego z Jagiellonów, Warszawa 1977, s. 61; S. Cynarski, Zygmunt August, Wrocław 2004, s. 26; L. Kolankowski, Zygmunt August Wielki Książę Litwy do roku 1548, Lwów 1913, s. 338.

${ }^{2} \mathrm{Na}$ mocy aktu z 6 października 1544 r. Zygmunt August otrzymał władzę na Litwie od Zygmunta I Starego (władzę sądowniczą, prawo do obsadzania urzędów świeckich oraz duchownych, a także prawo do rozporządzania dobrami wielkoksiążęcymi). Jego ojciec zostawił sobie władzę zwierzchnią nad Litwą oraz prawo do zarządzania publicznym skarbem litewskim, zob. S. Cynarski, Zygmunt August, s. 39-40. W Wilnie Zygmunt August przebywał już od marca 1544 r. Potwierdzają to rachunki dworu królewskiego zachowane w Archiwum Głównym Akt Dawnych (dalej: AGAD), zob. AGAD, Rachunki Królewskie 115, k. 25v-27v.

${ }^{3}$ A. Sucheni-Grabowska, Zygmunt August. Król polski i wielki książę litewski 1520-1562, Kraków 2010, s. 99. L. Kolankowski podał, że Zygmunt August przed formalnym objęciem władzy przebywał w mieście w latach: 1528-1529, 1533-1536, 1540-1542, zob. idem, Zygmunt August, s. 338.

${ }^{4}$ Jako badacz dziejów litewskiej stolicy Józef Ignacy Kraszewski został niejako ponownie odkryty przez Karolinę Sołtys. zob. eadem, Józef Ignacy Kraszewski jako historyk. Naukowy fundament wykładu dziejów Litwy w monografii Wilna, Warszawa 2013. Pamiętać jednak należy, że badania J.I. Kraszewskiego jako historyka miasta są w obiegu naukowym od dwóch stuleci. Pomocne zatem będą inne prace, zwłaszcza te poświęcone historii miasta (M. Baliński, Historya miasta Wilna, 1-2, Wilno 1836; idem, Opisanie statystyczne miasta Wilna, Wilno 1835; idem, Dawna Akademia Wileńska. Próba jej historyi od założenia w roku 1579 do ostatecznego jej przekształcenia w 1803 roku, Petersburg 1862; M. Łowmiańska, Wilno przed najazdem moskiewskim 1655 roku, [w:] Dwa doktoraty z Uniwersytetu Stefana Batorego w Wilnie, Poznań 2005, s. 151-329); Kościoła katolickiego (J. Kurczewski, Biskupstwo wileńskie od jego założenia aż do dni obecnych, zawierające dzieje i pracę biskupów i duchowieństwa diecezji wileńskiej oraz wykaz kościołów, klasztorów, szkół i zakładów dobroczynnych i społecznych, Wilno 1912; idem, Kościół Zamkowy, czyli Katedra Wileńska: w jej dziejowym, liturgicznym, architektonicznym i ekonomicznym rozwoju, 1, Wilno 1908; 2: Źródła historyczne na podstawie aktów kapitulnych i dokumentów historycznych, Wilno 1910; 3: Streszczenie aktów kapituły wileńskiej, Wilno 1916); biografie Zygmunta Augusta czy też publikacje, w których scharakteryzowana została organizacja królewskiego dworu (kluczowe znaczenie mają prace: M. Ferenc, Dwór Zygmunta Augusta: organizacja i ludzie, Kraków 1998; A. Marchwińska, Królewskie dwory żon Zygmunta Augusta: organizacja i składy osobowe, Toruń 2008), a także: S. Świerzewski, Józef Ignacy Kraszewski jako historyk Litwy. W setną rocznicę jubileuszu J.I. Kraszewskiego (1879), Kultura i Społeczeństwo XXII, 4, 1978, s. 109-127; H. Beresnevičiūtè, J.I. Kraševskis - Lietuvos istorikas, Darbai ir dienos, 1 (10), Kaunas 1995, s. 19-42. 
tomach w latach 1840-1842 w oficynie Józefa Zawadzkiego ${ }^{5}$. Intersujący nas okres opisany został w pierwszej części, przedstawiającej „dzieje ogólne miasta”, od czasów najdawniejszych aż do panowania Zygmunta III Wazy. Warto wspomnieć, że Kraszewski, pisząc monografię Wilna, opierał się na materiałach źródłowych, z których jedynie część zachowała się do czasów dzisiejszych ${ }^{6}$. Wydaje się zatem, że przedstawiony przez historyka obraz jest szczególnie cenny dla współczesnych badaczy dziejów Litwy i jej stolicy ${ }^{7}$.

Wilno bez wątpienia odegrało istotną rolę w życiu Zygmunta Augusta ${ }^{8}$. Zarazem, jak wiadomo, wiele mu zawdzięczało; za jego panowania przeżywało okres wszechstronnego rozwoju. Spośród licznych zagadnień analizowanych zazwyczaj w monografiach miast w niniejszym artykule uwzględnimy przede wszystkim tematykę związaną z życiem codziennym jego mieszkańców, zabudową i infrastrukturą litewskiej stolicy. Poza kręgiem rozważań znajdzie się natomiast charakterystyka programu architektonicznego siedziby wielkoksiążęcej jako rezydencji monarszej Jagiellona.

W zakresie sformułowanej tematyki nasuwają się pytania: jaki obraz Wilna i jego mieszkańców w czasach Zygmunta Augusta został przedstawiony przez Józefa Ignacego Kraszewskiego, na ile, w ciągu niemal trzydziestoletnich rządów syna Zygmunta I na Litwie, według autora czterotomowego dzieła, zmianie uległo życie wilnian ${ }^{9}$, w jaki sposób obecność monarchy oraz jego dworów oddziaływała na sferę życia publicznego Wilna. W tym miejscu należy zastrzec, że w artykule nie będą omawiane przemiany, jakie zostały wprowadzone $\mathrm{w}$ zakresie prawa czy administracji, ani nadanych miastu przywilejów $^{10}$. To zagadnienie wymaga odrębnej analizy. Warto jedynie do-

${ }^{5}$ J.I. Kraszewski, Wilno, 1-2, Wilno 1840; 3, Wilno 1841; 4, Wilno 1842.

${ }^{6}$ Materiały, w oparciu o które powstały dzieje Wilna, próbowała zidentyfikować K. Sołtys. Zob. eadem, Józef Ignacy Kraszewski, s. 83-141.

${ }^{7}$ Warto wspomnieć choćby rękopis wójta wileńskiego Tomasza Bildziukiewicza, zob. A. Ragauskas, Vilniaus miesto valdantysis elitas XVII a. antrojoje puseje (1662-1702 m.), Vilnius 2002, s. 74; M. Paknys, Vilniaus miestas ir miestiečiai 1636 m.: namai, gyventojai, svečiai, Vilnius 2006, s. 32, 35. Źródła, z których korzystał Kraszewski, opisując panowanie Zygmunta Augusta, wskazała K. Sołtys, zob. eadem, Józef Ignacy Kraszewski, s. 97-98.

${ }^{8}$ Władysław Kowalenko pisał, że „Zygmunt August ze wszystkich miast koronnych i litewskich najbardziej upodobał Wilno", zob. idem, Geneza udziału stołecznego miasta Wilna w Sejmach Rzplitej, Ateneum Wileńskie 4, 1927, s. 89.

${ }^{9} \mathrm{Z}$ pewnością zmiana ta właśnie za czasów Zygmunta Augusta musiała być bardzo istotna, świadczy o tym fakt, że doszło do zapewnienia Wilnu - na równi z Krakowem - udziału w sejmach, zob. ibidem, s. 90-91, 108-109, 128-129.

${ }^{10}$ Zbiór praw y przywilejów miastu stołecznemu W.X.L. Wilnowi nadanych wielu miast koronnych, jako też Wielkiego Księstwa Litewskiego, ułożony y wydany przez Piotra Dubińskiego burmistrza Wileńskiego, Wilno 1788. 
dać, że młody Jagiellon był świadkiem uregulowania przez ojca Zygmunta I Starego stosunków pomiędzy magistratem a mieszczanami. Funkcjonujący w oparciu o prawo magdeburskie samorząd wileński w chwili przejmowania przez Zygmunta Augusta władzy w Wielkim Księstwie Litewskim był już całkowicie ukształtowany ${ }^{11}$.

Kraszewski znany jest z dzieł pełnych pasji, dlatego nie dziwi, że i o stolicy Wielkiego Księstwa pisał z zaangażowaniem, zafascynowany jego historią ${ }^{12}$. Prawdopodobnie zamiłowanie to wynikało $\mathrm{z}$ więzi emocjonalnych, które połączyły go z miastem nad Wilią w $1829 \mathrm{r}$., gdy rozpoczął w nim studia medyczne. Za namową ojca porzucił je na rzecz zgłębiania wiedzy o literaturze $^{13}$. Historyk, chcąc podkreślić rolę Wilna oraz jego status na tle innych miast, opisywał jego dzieje także w kontekście wydarzeń dotyczących całej Rzeczpospolitej Obojga Narodów ${ }^{14}$. Warto dodać, że Kraszewski w swym czterotomowym dziele najbardziej „malowniczo” przedstawił właśnie panowanie Zygmunta Augusta ${ }^{15}$. Czy szczególne upodobanie tego okresu wynikało z faktu, że uważał go za najbardziej pomyślny w dziejach Polski i Litwy? To pytanie musi pozostać otwarte.

Historia Wilna w czasach ostatniego z Jagiellonów została opisana przez badacza $w$ dwóch przedziałach chronologicznych. Pierwszy wyznaczały daty 1529-1543, kiedy to Zygmunt August przybywał do Wilna w towarzystwie rodziców i nie miał bezpośredniego wpływu na transformacje zachodzące w stolicy za sprawą decyzji podejmowanych przez jego ojca. Drugi zaś to lata 1544-1572, kiedy według Kraszewskiego kluczowy dla dziejów miasta był okres 1544-1548. W tym właśnie czasie Zygmunt August sprawował realną władzę w Wielkim Księstwie Litewskim ${ }^{16}$. Od 1549 r. był on nie tylko wiel-

${ }^{11}$ M. Łowmiańska, Wilno przed najazdem moskiewskim, s. 279-286.

${ }^{12}$ J.I. Kraszewski przed wydaniem „Wilna” na łamach prasy publikował artykuły dotyczące historii miasta, zob. idem, Bekieszówka pod Wilnem. Wyjątek z tomu IV Historii Wilna Biruta 1838 - przedruk: Przyjaciel Ludu 44, 1838/1839; idem, Wiadomość o kościółku św. Anny w Wilnie, z dołączeniem podania o budowniczych kościoła pt. Majster i czeladnik, Znicz 1834, s. 193-201; idem, Pożar zamku wileńskiego 1610. Szkic historyczny, Biruta 1837, s. 169-188 (przedruki tego szkicu oraz opinie o nim opublikowały później Zbieracz Literacki i Polityczny 3, 1837; Tygodnik Petersburski 81-82, 1837; Gazeta Wielkiego Xięstwa Poznańskiego 266, 1837). O tym, jak wiele miejsca poświęcił Kraszewski badaniom dziejów Wilna, świadczy też bibliografia miejska: H. Baranowski, przy współpracy z Z. Baranowską i J. Goławską, Bibliografia Wilna, 2: Miasto, Toruń 2000.

${ }^{13}$ Bibliografia literatury polskiej „Nowy Korbut”, XII: Józef Ignacy Kraszewski. Zarys bibliograficzny, oprac. S. Stupkiewicz, I. Śliwińska, W. Roszkowska-Sykałowa, Warszawa 1966, s. 16.

${ }^{14} \mathrm{~K}$. Sołtys, Józef Ignacy Kraszewski, s. 26.

${ }^{15}$ Zauważyła to K. Sołtys, zob. ibidem, s. 97.

${ }^{16} \mathrm{O}$ zrzeczeniu się władzy w Wielkim Księstwie Litewskim przez Zygmunta I Starego na rzecz syna zob. J.I. Kraszewski, Wilno, 1, s. 241. 
kim księciem, ale przede wszystkim królem Polski. Podejmując próbę określenia, w jakich latach Wilno stanowiło główną rezydencję młodego Jagiellona, nie należy zapominać o roku 1551, kiedy to po śmierci Barbary przybył on do Wilna i pozostał w nim przez rok ${ }^{17}$, a także o latach 1551-1566, kiedy w mieście stołecznym Litwy spędzał dużo czasu ${ }^{18}$.

Poznane w 1529 r. przez Zygmunta Augusta Wilno, zgodnie z przekazem Józefa Ignacego Kraszewskiego, kilka miesięcy później było miastem już niemalże doszczętnie zniszczonym ${ }^{19}$. W wyniku pożogi, która nawiedziła stolicę 2 marca 1530 r., spalone zostało 2/3 jego zabudowy, prawdopodobnie $\mathrm{w}$ większości jeszcze drewnianej ${ }^{20}$. Pożar uszkodził zarówno budynki mieszkalne, jak i użytku publicznego, w tym zwłaszcza świątynie katolickie oraz prawosławne ${ }^{21}$. Koniec trzeciej dekady XVI w. nie był łaskawy dla mieszkańców stolicy Wielkiego Księstwa Litewskiego. Po pożarze wilnianie zmagali się z kolejnym problemem, którym było rozprzestrzeniające się $\mathrm{w}$ mieście i na przedmieściach morowe powietrze ${ }^{22}$. Na skutek klęsk, które nawiedziły Wilno, stolicę odbudowywano przez kolejnych kilkadziesiąt lat ${ }^{23}$. Część stawianych domów, kamienic oraz świątyń była już

${ }^{17}$ Ibidem, s. 250.

${ }^{18}$ M. Janicki, Górnicki, Kochanowski, Nidecki - wspólne lektury, wzajemne inspiracje? Kilka uwag o środowisku humanistycznym kancelarii Zygmunta Augusta w Wilnie, [w:] P. Salwa (red.), Łukasz Górnicki i jego włoskie inspiracje. Materiały z sesji zorganizowanej przez Komisję Dziejów Odrodzenia i Reformacji przy Komitecie Nauk Historycznych PAN (Warszawa, 28-29 listopada 2003), Warszawa 2005, s. 66, przyp. 8. Ustalenia Marka Janickiego można doprecyzować i uzupełnić o badania Władysława Kowalenko, który wykazał, że Zygmunt August w okresie od lipca 1551 r. do marca 1566 r. w Wilnie spędził przeszło 60 miesięcy, zob. idem, Geneza udziału, s. 89, przyp. 4.

${ }^{19} \mathrm{O}$ XVII-wiecznych pożarach Wilna pisał J. Paszenda. XVI-wieczne katastrofy wywołane przez pożary, nie zostały jak dotąd przeanalizowane zob. idem, Wpływ pożarów Wilna na architekturę późnego baroku, [w:] J. Lileyko (red.), Sztuka ziem wschodnich Rzeczypospolitej XVI-XVIII w., Lublin 2000, s. 487-494.

${ }^{20}$ Warto w tym miejscu przywołać słowa Gilberta de Lannoya, który odwiedzając Wilno na początku XV w., stwierdził, że znajdują się w nim brzydkie, drewniane domy i kilka murowanych kościołów. J. Fijałek, Opisy Wilna aż do połowy wieku XVII-go, Ateneum Wileńskie 1, 3-4, 1923, s. 316; idem, Opisy Wilna aż do połowy wieku XVII-go. Przegląd opisów Wilna od r. 1414 aż do połowy w. XVII-go z uwydatnieniem ich właściwości i wzajemnego do siebie stosunku, Ateneum Wileńskie 2, 1924, s. 122-158, 506-526.

${ }^{21}$ J.I. Kraszewski, Wilno, 1, s. 218. Skutki pożaru zostały również odnotowane w aktach kapituły katedralnej wileńskiej, zob. Kościół Zamkowy, 3, s. 32-33.

${ }^{22}$ J.I. Kraszewski, Wilno, 1, s. 219. Pojawienie się zarazy w sierpniu 1531 r. odnotowano w aktach kapituły wileńskiej, zob. Kościół Zamkowy, 3, s. 33.

${ }^{23}$ J.I. Kraszewski podał, że miasto podnosiło się z pożogi do 1559 r. Z przeglądu kamienic dokonanego w tym roku przez Kapitułę wynika, że wszystkie zniszczone budynki zostały odbudowane, zob. idem, Wilno, 1, s. 218. Kilka kart dalej pisał on „Pożar nawet 1530 roku, po którym ledwie w lat sześć skończyło się zupełnie zabudowywać, [...]”, ibidem, s. 229. 
murowana ${ }^{24}$. Uporządkowano również sferę sacrum, którą wyznaczała przestrzeń przykościelnych cmentarzy. Miejsca ostatniego spoczynku wilnian od przestrzeni użytku codziennego oddzielono murami ${ }^{25}$. Efektem przeprowadzonych w następnych latach prac było wzmocnienie bezpieczeństwa mieszkańców stolicy. W tym celu umocniono mury oraz wały ${ }^{26}$. Wraz z nastaniem kolejnej dekady rozpoczął się proces swoistej przebudowy i rozbudowy miasta z drewnianego na murowane, którego szczyt przypadł właśnie na panowanie Zygmunta Augusta. W efekcie Wilno u schyłku XVI w. było już w większości murowane, zaś drewniane, jak wskazała Maria Łowmiańska, pozostały zaułki i boczne uliczki ${ }^{27}$. Warto dodać, że w mieście podjęte zostały działania, które miały ułatwić walkę mieszkańców z żywiołem ognia. Jak podał Kraszewski, prócz obowiązku stawienia się z wiadrami podczas pożaru, który nałożono na wszystkich mieszkańców Wilna, obronę miasta przed płomieniami miało wspomóc użycie sikawek darowanych przez Zygmunta Augusta ${ }^{28}$.

Ostatni władca $\mathrm{z}$ dynastii Jagiellonów był świadkiem istotnych zmian zachodzących w infrastrukturze Wilna. Miasto, które stawało się mu coraz bliższe, posiadało kilkanaście kościołów katolickich i tyleż cerkwi; według danych z początku XVI w. pierwszych było w Wilnie 14, drugich $-15^{29}$. Józef Ignacy Kraszewski wspomina, że w mieście działał szpital św. Marii Magdaleny, w którym schronienie mogli znaleźć chorzy, a także przykościelne domy prowadzone przez różne zgromadzenia zakonne, oferujące pomoc i wsparcie dla najuboższych ${ }^{30}$. Istniały także łaźnie, które przetrwały od czasów Jagiełły i Witolda ${ }^{31}$.

\footnotetext{
${ }^{24}$ R. Janonienè, Budownictwo murowane, [w:] Kultura Wielkiego Księstwa Litewskiego analizy i obrazy, oprac. V. Ališauskas, L. Jovaiša, M. Paknys, R. Petrauskas, E. Raila, tłum. P. Bukowiec, B. Kalęba, B. Piasecka, Kraków 2006, s. 116-117.

${ }^{25}$ J.I. Kraszewski, Wilno, 1, s. 229. E. Gołębiowski, Zygmunt August, s. 124.

${ }^{26}$ Wilno zostało otoczone murem na mocy przywileju wydanego przez Aleksandra Jagiellończyka w 1503 r. Zbiór praw y przywilejów miastu stołecznemu W.X.L. Wilnowi nadanych, s. 19-20, 29. Przebieg muru zob. M. Łowmiańska, Wilno przed najazdem moskiewskim, s. 168-171. Zob. też: J.I. Kraszewski, Wilno, 1, s. 226.

${ }^{27}$ M. Łowmiańska, Wilno przed najazdem moskiewskim, s. 187.

${ }^{28}$ Kraszewski wspomniał, że Jagiellon po pożarze z 1542 r. zamówił 100 sikawek dla Wilna, które wykonano w Krakowie, zob. idem, Wilno, 1, s. 226, 236.

${ }^{29}$ J. Ochmański, Biskupstwo wileńskie w średniowieczu. Ustrój i uposażenie, Poznań 1972, s. 80-81, przyp. 423. Zob. J.I. Kraszewski, Wilno, 1, s. 241.

${ }^{30} \mathrm{~W} 1518 \mathrm{r}$. Zygmunt I nadał plac pod budowę szpitala. Zob. J. Kurczewski, Kościół Zamkowy, 2, s. 176. J. Maroszek, Wileńskie przytułki - szpitale w XVI-XVIII w., [w:] C. Kuklo (red.), P. Guzowski (wsp.), Cała historia to dzieje ludzi...: studia $\mathrm{z}$ historii społecznej ofiarowane profesorowi Andrzejowi Wyczańskiemu w 80-tą rocznicę urodzin i 55-lecie pracy naukowej, Białystok 2004, s. 191-217; J.I. Kraszewski, Wilno, 1, s. 229.
}

${ }^{31}$ J.I. Kraszewski, Wilno, 1, s. 227. 
Z perspektywy urbanistycznej szczególnym przedsięwzięciem dla mieszkańców Wilna była budowa w 1536 r. mostu na Wilii ${ }^{32}$. Fakt ten został odnotowany przez Józefa Ignacego Kraszewskiego, który podkreślił, że połączenie obu brzegów było ważne zwłaszcza z powodów gospodarczych i społecznych, gdyż umożliwiało przewóz żywności do wilnian mieszkających po drugiej stronie rzeki, ułatwiało handel oraz komunikację ${ }^{33}$. Decyzja o jego budowie została podjęta w 1535 r., a jej rzecznikiem był Ulrych Hozjusz, ówczesny horodniczy wileński ${ }^{34}$. Pomysł został pozytywnie przyjęty przez Zygmunta I Starego, który zobowiązał urzędnika do wybudowania mostu własnym kosztem. W celu odzyskania wyłożonych przez Hozjusza pieniędzy król zezwolił horodniczemu pobierać przez jakiś czas mostowe. $Z$ dochodu, który most przynosił w dalszych latach, władca rozkazał wybudować przy dominikańskim kościele pw. św. Ducha szpital dla ubogich i chorych (Świętej Trójcy) ${ }^{35}$. W rok po przejęciu przez Zygmunta Augusta władzy na Litwie (1545 r.) Hozjusz odmówił zarządzania mostem. Poprosił Jagiellona o wyznaczenie innej osoby, która mogłaby zająć się jego administrowaniem. Zygmunt August oddał most oraz szpital pod nadzór i opiekę magistratu wileńskiego ${ }^{36}$. Wypada $\mathrm{w}$ tym miejscu dodać, że wielki książę ufundował także szpital przy cerkwi Spaskiej37.

Kraszewski wspomina, że regulacjom poddane zostało również życie gospodarcze mieszkańców miasta. W stolicy Wielkiego Księstwa Litewskiego działały bractwa kupieckie i rzemieślnicze. Już za panowania Aleksandra w Wilnie utworzono bractwo złotnicze, którego statuty zostały potwierdzone przez Zygmunta I Starego w 1516 r., a następnie przez Zygmunta Augusta ${ }^{38}$. Oprócz złotników w mieście stołecznym działały także bractwo krawieckie ${ }^{39}$ i balwierskie ${ }^{40}$. Zygmunt I nadał statuty cechom: kowali, kotlarzy i ślusarzy.

\footnotetext{
${ }^{32}$ Józef Maroszek wskazuje, że potrzeba budowy mostu na Wilii wynikała z klęski, jaką spowodował pożar, który nawiedził miasto w 1530 r., zob. idem, Wileńskie przytułki - szpitale, s. 199.

${ }^{33}$ J.I. Kraszewski, Wilno, 1, s. 222.

${ }^{34}$ Urzędnicy Wielkiego Księstwa Litewskiego. Spisy, 1: Województwo wileńskie XIV-XVIII wiek, red. A. Rachuba, oprac. H. Lulewicz, A. Rachuba, P.P. Romaniuk; wsp. U. Jemialianczuk, A. Macuk, Warszawa 2004, s. 102. Za czasów Aleksandra był on zarządcą Mennicy Wileńskiej.

${ }^{35}$ J.I. Kraszewski, Wilno, 1, s. 222-223; J. Maroszek, Wileńskie przytułki - szpitale, s. 199-204.

${ }^{36}$ J.I. Kraszewski, Wilno, 1, s. 244.

${ }^{37}$ J. Kurczewski, Biskupstwo wileńskie, s. 363.

${ }^{38}$ J.I. Kraszewski, Wilno, 1, s. 257-258. Zob. też: Akty cechów wileńskich 1495-1759 (dalej: ACW), zeb. i oprac. H. Łomiański, wsp. M. Łowmiańska, S. Kościałkowski, przedm. i skorowidze J. Jurkiewicz, Poznań 2006, s. 1-4; ibidem, s. 11-12, 39-40. Bractwo to otrzymało zezwolenie na odprawianie nabożeństwa w farze świętojańskiej w Wilnie, ibidem, s. 12. B.R. Vitkauskiene, Złotnictwo wileńskie: ludzie i dzieła XV-XVIII wiek, Warszawa 2006.

${ }^{39}$ ACW, s. 4-6.

${ }^{40}$ Ibidem, s. 7-9.
} 
Uregulował również prawa $\mathrm{w}$ zakresie handlu skórami ${ }^{41}$, nadał przywileje szewcom, zatwierdził statuty brackie kuśnierzy ${ }^{42}$. Wzrostową tendencję w kierunku zrzeszania się rzemieślników będzie można zaobserwować również podczas rządów Zygmunta Augusta. W 1552 r. ustanowił on cech słodowniczy, cech szewski oraz cech chirurgów, 10 lat później - cech siodlarzy, rymarzy, paśników i stolarzy ${ }^{43}$. Warto dodać, że $\mathrm{w}$ mieście działały także bractwa religijne zrzeszające osoby duchowne oraz świeckie, których głównym celem była działalność religijna ${ }^{44}$. Na nich to w kwestii funkcjonowania wzorowały się bractwa rzemieślnicze. Zarówno organizacje religijne, jak i rzemieślnicze będą odgrywały znaczącą rolę w życiu publicznym miasta ${ }^{45}$.

Jak podał Józef Ignacy Kraszewski, to Zygmunt I Stary uporządkował przestrzeń wokół rynku, wydając pozwolenie, aby w dwóch rzędach były rozstawiane kramy dla handlujących tam szewców, skórników, garncarzy, solenników, rymarzy i innych rzemieślników oraz kupców ${ }^{46}$. Porządek ten będzie się utrzymywać przez kolejne wieki. W tej części miasta koncentrował się handel lokalny, który w głównej mierze zaspokajał potrzeby ludności miejskiej oraz przybywającej do miasta szlachty. Warto dodać, że król nie zapomniał również o tych, którzy do miasta zjeżdżali głównie w celach handlowych. Zygmunt I Stary nakazał rozbudować dom gościnny, w którym mogli zatrzymywać się kupcy ruscy (moskiewscy), tureccy oraz włoscy ${ }^{47}$. Przybywający $\mathrm{z}$ terenów Wielkiego Księstwa Moskiewskiego kupcy byli z pewnością znacznie liczniejsi, nie tylko od kupców tureckich, ale także włoskich ${ }^{48}$.

Wraz z Zygmuntem Augustem w Wilnie rezydował jego dwór ${ }^{49}$. Został on do stolicy przeniesiony 5 kwietnia $1544 \mathrm{r} \cdot{ }^{50}$ Należy pamiętać, że w latach 1544-1548 Jagiellon dysponował dwoma odrębnymi dworami - polskim oraz litewskim. Pierwszy z nich został uformowany w połowie 1543 r., drugi zaś

${ }^{41}$ Ibidem, s. 9-14, 63-65.

${ }^{42}$ Ibidem, s. 22-26, 60.

${ }^{43}$ Ibidem, s. 42-46, 48-49, 59, 60-62.

${ }^{44}$ A. Kaladžinskaitè, Brolijų dailès užsakymai Vilniuje XVIII a., Dailès istorijos studijos, 2: Dailè LDK miestuose: poreikiai ir užsakymai, Vilnius 2006, p. 145-164.

${ }^{45}$ L. Jovaiša, Bractwa, [w:] Kultura, s. 92-113, 100-103.

${ }^{46}$ J.I. Kraszewski, Wilno, 1, s. 225.

${ }^{47}$ Ibidem, s. 226.

${ }^{48}$ M. Łowmiańska wspomina, że do Wilna towary napływały z Indii, z Hiszpanii, z Francji, Anglii, Szkocji, z Danii, z Niemiec, z Rakusz, Moskwy, a także z Włoch oraz Turcji, zob. M. Łowmiańska, Wilno przed najazdem moskiewskim, s. 263.

${ }^{49}$ Władysław Kowalenko, powołując się na ustalenia Kolankowskiego, wskazał, że dwór polski w Wilnie został utworzony wiosną 1537 r. Zob. idem, Geneza udziału, s. 89.

${ }^{50}$ A. Sucheni-Grabowska, Zygmunt August, s. 105. Na temat dworu Zygmunta Augusta zob. L. Kolankowski, Zygmunt August. 
w październiku 1544. Jak zauważył Ludwik Kolankowski, ten ostatni nigdy nie został zorganizowany $\mathrm{w}$ całości ${ }^{51}$. Dwór litewski stanowił jedynie namiastkę tego, o czym marzyło litewskie ziemiaństwo. Olbrzymie wydatki ponoszone na utrzymanie dużego, polskiego zespołu administracyjnousługowego uniemożliwiały powołanie $z$ podobnym rozmachem dworu litewsko-ruskiego ${ }^{52}$. Wraz z Zygmuntem i jego małżonką w Wilnie przebywały trzy dwory. Tak było od października 1544 do czerwca 1545 r., gdy w stolicy u boku wielkiego księcia rezydował dwór polski oraz litewski, a także dwór jego żony, młodej królowej Elżbiety ${ }^{53}$. Do stolicy przybywały również dwory dwóch pozostałych małżonek. Zaledwie trzy lata (1548-1551) działał dwór Barbary Radziwiłłówny, zaś trzynaście lat (1553-1566) dwór Katarzyny Habsburżanki ${ }^{54}$. Wydaje się, że dwór Radziwiłłówny był najbliższy mieszkańcom Wielkiego Księstwa Litewskiego. W znacznej mierze współtworzyli go Polacy, a także przedstawiciele narodowości zamieszkujących ziemie Wielkiego Księstwa Litewskiego od wieków, czyli Rusini i Litwini. Obcokrajowców było zaledwie dwóch - krawiec włoskiego pochodzenia oraz sługa garderobiany wywodzący się z Węgier. Nie będzie zatem błędem nazwanie tego dworu polsko-litewskim ${ }^{55}$. Znacznie bardziej zróżnicowany pod względem narodowościowym był dwór Katarzyny. Zdecydowanie miał on charakter polskoniemiecki, o czym świadczy osobny fraucymer Niemek, choć obecni byli tam także Włosi, Murzynka - karlica królowej oraz Pers, który był lokajem ${ }^{56}$.

Obecność monarchów oraz ich dworów przyczyniła się do przekształcenia pałacu wielkoksiążęcego w rezydencję królewskąa ${ }^{57}$. Józef Ignacy Kraszewski na kartach swej pracy wspomina, że to Zygmunt Stary rozpoczął przebudowę zamku. Historyk nie podał jednak szczegółów związanych z podjętymi pra-

${ }^{51}$ L. Kolankowski, Zygmunt August, s. 316. Władysław Kowalenko wskazał, że utworzony dwór litewski nie był tak „pełny” jak dwór polski i posiadał drugorzędne znaczenie. Zob. W. Kowalenko, Geneza udziału, s. 90.

${ }^{52}$ A. Sucheni-Grabowska, Zygmunt August, s. 125.

${ }^{53}$ A. Marchwińska, Królewskie dwory żon Zygmunta Augusta.

${ }^{54}$ Dwór utworzony przez Zygmunta dla Barbary był złożony z matron polskich, zob. W. Kowalenko, Geneza udziału, s. 89. Katarzyna w Wilnie była prawdopodobnie od 1554 do 1558 r. Do stolicy Wielkiego Księstwa Litewskiego udała się ponownie w 1559 r. Zob. S. Cynarski, Zygmunt August, s. 66.

${ }^{55}$ A. Marchwińska, Rejestr dworu królowej Barbary (1548-1551), Studia Źródłoznawcze 38, 2000, s. 86 .

${ }^{56}$ Eadem, Królewskie dwory żon Zygmunta Augusta, s. 160.

${ }^{57}$ J. Maroszek, Ogrody królewskie w Wilnie i innych rezydencjach Wielkiego Księstwa Litewskiego w XVI wieku, [w:] M. Szafrańska (red.), Królewskie ogrody w Polsce: materiały sesji naukowej, Warszawa, 10-11 maja 2001 roku (The royal gardens in Poland: conference materials, Warsaw, May 10-11, 2001), Towarzystwo Opieki nad Zabytkami, Warszawa 2001, s. 109-110. 
cami. Wskazał jedynie, że rozpoczęte przez ojca działania były kontynuowane przez syna ${ }^{58}$. Według relacji Kraszewskiego Zygmunt August do dawnej rezydencji nakazał dobudować skrzydło zwane później Pałacem Nowym, oficyny oraz pomieszczenia dla swego dworu ${ }^{59}$. Prace te zlecił Giovanniemu Ciniemu, Giovanniemu Marii Mosce, a także Padovanowi i Filippowi Bartolommeo da Fiesolemu. Siedziba wielkich książąt litewskich, reprezentująca najcenniejsze wartości i tradycje, stała się rezydencją Zygmunta Augusta, jego dworu, a także dworów jego trzech małżonek ${ }^{60}$. Pałac, obok którego założono ogród, stał się ośrodkiem kultury i sztuki renesansowej oraz wczesnobarokowej $^{61}$. To tutaj przyjmowane były poselstwa zagraniczne ${ }^{62}$, tutaj również redagowano I Statut Litewski, przechowywano Metrykę Litewską i wydawano wyroki. Król, jak wspomina Kraszewski, zgromadził na zamku znaczną bibliotekę, która pozostawała w latach 1559-1568 r. pod opieką Łukasza Górnickiego ${ }^{63}$.

Józef Ignacy Kraszewski sporo miejsca poświęcił informacjom na temat ważnych uroczystości dworskich, dla których Wilno stało się sceną. Już pod datą 1533 r. odnotowuje on uroczysty wjazd rodziny królewskiej do stołecznego miasta. $\mathrm{W}$ dalszej części informuje, że w orszaku prowadzącym Zygmunta I Starego, Bonę oraz Zygmunta Augusta, prócz dworzan, kroczyło również 4 tys. jeźdźców. Historyk stwierdził, że przybycie króla z rodziną mieszkańcy Wilna przyjęli „radośnie”" Kilka lat później, w 1540 r. wilnianie świętowali narodziny Jana II Zygmunta Zapolyi, syna Izabeli Jagiellonki córki

\footnotetext{
${ }^{58}$ Wiadomo, że Zygmunt I Stary rozszerzył rezydencję na Zamku Dolnym i wybudował pałac w stylu renesansowym. Przebudowa pałacu została ukończona przed pożarem w $1530 \mathrm{r}$. Wpływ na dalszy jego rozwój miała niewątpliwie Bona Sforza. Dążyła ona do przekształcenia wileńskiego pałacu w reprezentacyjną rezydencję Jagiellonów, która miała dorównywać lub też przewyższać zamek w Krakowie. W tym celu sprowadziła do Wilna: Bartolommea Berrecciego, Benedykta Sandomierzanina oraz Bernardina Zanobiego de Gianotisa.

${ }^{59}$ J.I. Kraszewski, Wilno, 1, s. 239.

${ }^{60}$ Jagiellonki polskie w XVI wieku. Obrazy rodziny i dworu Zygmunta I. i Zygmunta Augusta Królów Polskich, 1, wyd. A. Przeździecki, Kraków 1868, s. 108-111; S. Cynarski, Zygmunt August, s. 34-36; A. Sucheni-Grabowska, Zygmunt August, s. 68, 101.

${ }^{61} \mathrm{~J}$. Maroszek, Ogrody królewskie w Wilnie, s. 109-110.

${ }^{62}$ J.I. Kraszewski, Wilno, 1, s. 221, 222. W 1535 r. w Wilnie przebywał książę Albrecht Hohenzoller, S. Cynarski, Zygmunt August, s. 31.

${ }^{63}$ Szerzej na temat daty nominacji zob. M. Janicki, Aneks: Łukasza Górnickiego stanowisko bibliotekarza i sekretarza królewskiego (1559-1568), [w:] idem, Górnicki, Kochanowski, Nidecki, s. $80-84$.

${ }^{64}$ Zgodnie z informacją podaną na kartach „Wilna”, Zygmunt August w 1533 r. uczestniczył w pogrzebie Konstantego Ostrogskiego wojewody trockiego, zmarłego w sierpniu 1530 r. Zob. Z. Wojtkowiak, Ostrogski Konstanty (ok. 1460-1530), Polski Słownik Biograficzny 24, 1979, s. $486-489$.
} 
królewskiej i żony króla węgierskiego Jana Zapolyi. Z tej okazji w stolicy Wielkiego Księstwa Litewskiego zorganizowane zostały „wielkie wesołe uroczystości” oraz wyprawiane były dla wilnian uliczne „bankiety”. Obchody uroczystości uświetniały pokazy puszkarskich ogni oraz wystrzały z dział rozstawionych zapewne na Górze Zamkowej ${ }^{65}$. Kraszewski podał, że kilka dni po tej radosnej nowinie do przebywającego w mieście króla dotarła informacja, że zmarł jego zięć. Niestety historyk nie wspomniał nic na temat ewentualnych uroczystości żałobnych. Wydaje się, że takowe musiały mieć miejsce w Wilnie ${ }^{66}$.

$\mathrm{Na}$ miano jednych $\mathrm{z}$ najwspanialszych uroczystości dworskich, jakie odbyły się w XVI w., mógł prawdopodobnie zasługiwać wjazd do Wilna w dniu 22 października 1544 r. Zygmunta Augusta i jego małżonki Elżbiety Habsburżanki. Józef Ignacy Kraszewski nie poświęcił jednak temu wydarzeniu szczególnej uwagi. Historyk odnotował jedynie że, „Zaraz tedy z Brześcia w r. 1544 Zygmunt August otoczony panami, z młodą żoną swoją wyruszył do Wilna na mieszkanie" ${ }^{67}$. Trudno jednoznacznie stwierdzić, skąd w tym wypadku tak małe zainteresowanie ze strony badacza tym wydarzeniem. Być może wynikało ono z braku materiału źródłowego, na którym mógłby on oprzeć opis. Możemy jedynie przypuszczać, że orszak monarszej (królewskiej) pary był prowadzony głównym traktem królewskim. Ten, jak ustalono, do połowy XVII w. wyznaczały: z jednej strony kościół katedralny, z drugiej zaś przedmieścia znajdujące się za Bramą Rudnicką, przy późniejszym kościele św. Stefana (ufundowany na początku XVII w.). Mając na uwadze fakt, że tędy prowadził trakt rudnicki zwanym również krakowskim, przypuszczać możemy, że królewska para do Wilna wjechała przez Bramę Rudnicką, a następnie podążała $\mathrm{w}$ kierunku placu ratuszowego ulicami stanowiącymi „kręgosłup urbanistyczny" miasta - Wielką i Zamkową - udała się w stronę stojącego u podnóża Góry Zamkowej kościoła katedralnego ${ }^{68}$. Warto wspomnieć, że to dzięki Jagiellonom trasa ta zyskała miano „królewskiej” i stała się główną trasą ceremonialną, którą w kolejnych latach wjeżdżali monarchowie, a także wysokiej rangi dostojnicy zarówno państwowi, jak i kościelni ${ }^{69}$. Zmiana na-

${ }^{65}$ J.I. Kraszewski, Wilno, 1, s. 235.

${ }^{66}$ Ibidem, s. 236.

${ }^{67}$ Ibidem, s. 241. Zob. też Jagiellonki polskie w XVI wieku, s. 158-159; S. Cynarski, Zygmunt August, s. 38.

${ }^{68}$ G. Zujienè, Ceremoniał ingresu biskupów wileńskich w XVII-XVIII wieku, Barok. Historia literatura - sztuka 13/1, 2006, s. 67.

${ }^{69}$ J. Dorobisz, Pobyty Władysława IV Wazy w Wilnie i okolicach, [w:] E. Feliksiak, A. Mironowicz (red.), Wilno i Kresy północno-wschodnie: materiały II Międzynarodowej Konferencji w Białymstoku 14-17 IX 1994 r. w czterech tomach, 1: Historia i ludzkie losy, Białystok 1996, s. 61-74. 
stąpiła w II połowie XVII w., kiedy to trasa została przesunięta w kierunku Ostrej Bramy. Jak podaje A. Sucheni-Grabowska, wielkoksiążęca para w stolicy Wielkiego Księstwa Litewskiego była witana z wielką radością. Wilnianie mieli okazję uczestniczyć w wyjątkowej uroczystości, której splendoru dodawał fakt, że Zygmunt August wjazdem inaugurował swoje oficjalne rządy na Litwie $^{70}$. W tym miejscu wypada również wspomnieć, że to za czasów Jagiellonów w stolicy Wielkiego Księstwa Litewskiego umocniła się tradycja ofiarowywania przez Radę oraz wójtów przybywającym do miasta dostojnikom państwowym i kościelnym, podarków oraz honorariów ${ }^{71}$. Zwyczaj ten będzie praktykowany do końca XVIII w. nie tylko na okoliczność wjazdu do miasta wysokiego rangą dostojnika, ale również nastania świąt obchodzonych przez Kościół katolicki.

Niedługo przyszło mieszkać młodej królowej w Giedyminowym mieście. Jak wspomina Kraszewski, Elżbieta zmarła samotnie 15 czerwca 1545 r. w Wilnie na skutek choroby (licznych napadów konwulsji) ${ }^{72}$. Podobnie jak w wyżej przywołanych przykładach, tak i tutaj historyk nie przekazuje czytelnikowi szczegółów związanych z uroczystościami pogrzebowymi. Podał jedynie, że pogrzeb zaplanowano na 24 sierpnia, zaś trumnę z ciałem Habsburżanki złożono w kaplicy królewskiej w kościele zamkowym w obecności Zygmunta Augusta i jego ojca ${ }^{73}$. Większą uwagę historyk zwraca na fakt, że śmierć Elżbiety była wielką stratą i przysporzyła smutku wszystkim za wyjątkiem Bony ${ }^{74}$. Pewne informacje na temat pogrzebu zaczerpnąć można $z$ wiersza Jakuba Przyłuskiego - filologa, prawnika, poety łacińskiego i polskiego. Autor wskazał, że „pobożną królową” w ciszy i smutku żegnali odziani w żałobne stroje wilnianie. Ciało do grobu odprowadzone było przez „dom królewski” reprezentowany przez Zygmunta Augusta i jego rodziców, „radne pany”, królewskie dwory, lud oraz wojsko odziane w „czarne kaftany”. Na przodzie żałobnego konduktu kroczyły konie, przykryte czarnymi kapami, do których przyczepione były srebrne blachy z królewskimi herbami ${ }^{75}$. Anna Sucheni-Grabowska stwierdziła, że w wygłaszanych podczas uroczystości mowach podkreślano cnoty zmarłej, głównie jej łagodność, pobożność i uprzejmość ${ }^{76}$.

\footnotetext{
${ }^{70}$ A. Sucheni-Grabowska, Zygmunt August, s. 124.

${ }^{71}$ J.I. Kraszewski, Wilno, 1, s. 228.

${ }^{72}$ Jagiellonki polskie w XVI wieku, s. 165. J.I. Kraszewski, Wilno, s. 242-243.

${ }^{73}$ J.I. Kraszewski, Wilno, 1, s. 243.

${ }^{74}$ Ibidem, s. 242.

${ }^{75}$ Jagiellonki polskie w XVI wieku, s. 170-171.

${ }^{76}$ A. Sucheni-Grabowska, Zygmunt August, s. 129.
} 
Historyk na kartach swej pracy sporo miejsca poświęcił uczuciu, które połączyło Zygmunta Augusta i Barbarę Radziwiłłównę 77 . Budowa tajemnego przejścia łączącego zamek wielkoksiążęcy z pałacem radziwiłłowskim, sprzeciw ze strony Bony oraz panów polskich, a zwłaszcza potajemne zaślubiny w 1547 r. pary kochanków to najobszerniej opisane przez Kraszewskiego wątki tej miłosnej historii ${ }^{78}$. Nie wspomina on natomiast nic o ewentualnym zaprezentowaniu Barbary rodzicom młodego króla. Z literatury przedmiotu wiadomo, że kilka miesięcy po zawarciu związku małżeńskiego Barbara miała zostać oficjalnie przedstawiona Zygmuntowi I Staremu oraz Bonie jako poślubiona, prawowita małżonka i królowa. Zygmunt August powziął działania, których celem było przygotowanie wileńskich obchodów uroczystości godowych Jagiellona i Radziwiłłówny ${ }^{79}$. Zaplanowane na kwiecień 1548 r. huczne obchody uroczystości na cześć nowej królowej musiały zostać jednak odwołane $\mathrm{z}$ powodu śmierci króla ojca. Jak podał Józef Ignacy Kraszewski, 8 kwietnia 1548 r. do Wilna dotarła wiadomość o zgonie Zygmunta I Starego $^{80}$. Osiemdziesięcioletni król-ojciec zmarł w Wielkanoc 1 kwietnia $1548 \mathrm{r}$. w Krakowie ${ }^{81}$. Wilnianom tę smutną nowinę ogłosiły dzwony świątyń. Z okazji śmierci króla zarządzono wielką żałobę. W wileńskich świątyniach przy wystawionych marach oraz licznie rozstawionych świecach odprawiano uroczystości żałobne $^{82}$. Nie mając nad sobą już niczyjej władzy zwierzchniej, Zygmunt August bez zbędnych splendorów poinformował Radę Panów o swym ponownym ożenku oraz przedstawił nową królową ${ }^{83}$.

Kraszewski zaznaczył, że niedługo cieszył się Zygmunt August szczęściem u boku swej ukochanej. Po trzech latach samodzielnych rządów nad Koroną i Litwą 8 maja 1551 r. jego żona zmarła w Krakowie ${ }^{84}$. Historyk ponownie przemilczał uroczystości, które towarzyszyły temu wydarzeniu. Zapisał on jedynie, że:

77 Z. Kuchowicz, Barbara Radziwiłłówna, Łódź 1976, s. 122-160.

${ }^{78}$ J.I. Kraszewski, Wilno, 1, s. 248. Perypetie miłosne króla interesowały także Kraszewskiego poetę, co opisał w poemacie Barbara, zob. idem, Barbara [w:] Poezja, 1, Wilno 1838.

${ }^{79}$ L. Kolankowski, Zygmunt August, s. 345-346.

${ }^{80}$ Jagiellonki polskie w XVI wieku, s. 193.

${ }^{81}$ M. Kromer, Mowa na pogrzebie Zygmunta I oraz o pochodzeniu i o dziejach Polaków: księgi XXIX i XXX, Olsztyn 1982, s. 105-163; A. Sucheni-Grabowska, Zygmunt August, s. 168. Zob. też M. Rożek, Groby królewskie w Krakowie, Kraków 1977, s. 64-71.

${ }^{82}$ J.I. Kraszewski, Wilno, 1, s. 248.

${ }^{83}$ Jagiellonki polskie w XVI wieku, s. 195.

${ }^{84}$ J.I. Kraszewski, Wilno, 1, s. 250. K. Estreicher w Bibliografii odnotował: Narzekanye krolowy na nyesszczescye po smyerci. Drukowano w Krakowye przez Lazarza Jandrysa [1551]; Napis nad grobem zacney królowey Barbary Radziwiłłówny, niegdy będącey królowy polskiey. W Krakowie [...] M.D.LVIII, zob. K. Estreicher, Bibliografia polska, XII, Kraków 1910, s. 365. 
Prowadził jej ciało sam August do Wilna, do rodzinnych w Zamkowym Kościele grobów, nie chcąc aby spoczywała na niewdzięcznej ziemi, nie odstępując jej ciała ani na krok w tej smutnej podróży ${ }^{85}$.

$\mathrm{Na}$ podstawie innych relacji wiadomo, że zwłoki Barbary ubrane były w długą, atłasową, czarną suknię. W trumnie złożono również insygnia królewskie (koronę, berło oraz jabłko). Żałobnicy z Krakowa do Wilna wyruszyli 26 maja. Podróż trwała trzy tygodnie. Wóz żałobny prowadziły czarnej maści konie. W nocy przy trumnie sprawowane były egzekwie żałobne. Orszak 20 czerwca stanął w Rudnikach, zaś 23 odprawiony został uroczysty pogrzeb w wileńskim kościele katedralnym ${ }^{86}$. Zwłoki Barbary zostały złożone w tej samej kaplicy królewskiej, w której pochowano sześć lat wcześniej ciało Elżbiety ${ }^{87}$. Miało to być jednak tymczasowe miejsce spoczynku ukochanej Zygmunta Augusta. Król rozpoczął bowiem budowę na zamku wileńskim kościoła pw. św. Anny-Barbary ${ }^{88}$. Po jego ukończeniu to w nim miały zostać złożone zwłoki dwóch zmarłych żon Jagiellona. Świątynia miała również stanowić miejsce spoczynku samego Zygmunta Augusta, tak się jednak nie stało.

Kraszewski wskazał, że w kolejnych latach mieszkańcy Wilna uczestniczyli w uroczystościach zorganizowanych z okazji wjazdu do stolicy Wielkiego Księstwa Litewskiego trzeciej małżonki Zygmunta Augusta Katarzyny Habsburżanki, który miał miejsce w 1554 r., złożenia hołdu lennego przez Gotarda Kettlera w 1561 r. ${ }^{89}$ czy zaślubin siostry króla, Katarzyny Jagiellonki, z Wielkim Księciem Finlandii Janem, późniejszym królem Szwecji Janem III Wazą ${ }^{90}$.

$\mathrm{Na}$ kartach historii Wilna święta oraz uroczystości przeplatają się z troskami dnia codziennego jego mieszkańców. Te, jak pisał historyk, wynikały między innymi z głodu, który nastał w 1544 r. i był spowodowany inwazją szarańczy $^{91}$, czy też wystąpieniem w latach 1552-1555, a następnie 1569-1572 morowego powietrza ${ }^{92}$.

Zygmunt August kontynuował politykę rozwijania miasta zapoczątkowaną jeszcze przez Aleksandra. W Wilnie działały na większą skalę różne przed-

${ }^{85}$ J.I. Kraszewski, Wilno, 1, s. 250.

${ }^{86}$ Jagiellonki polskie w XVI wieku, s. 265-271.

${ }^{87}$ J.I. Kraszewski, Wilno, 1, s. 250.

${ }^{88}$ Więcej na temat kościoła zob. V. Drèma, Vilniaus bažnyčios. Iš Vlado Drèmos archyvų, oprac. A. Lèverienè, A. Mickevičius, R. Mosiejienè, Vilnius 2008, s. 692-720.

${ }^{89}$ J.I. Kraszewski, Wilno, 1, s. 264.

${ }^{90}$ Ibidem, s. 271-275.

${ }^{91}$ Ibidem, s. 240.

${ }^{92}$ Ibidem, s. 256-258, 283. 
siębiorstwa przemysłowe, w tym między innymi młyny, huta szkła ${ }^{93}$, postrzygalnia, woskobojnia ${ }^{94}$, działolejnia czy wileńska mennica ${ }^{95}$. Kraszewski wspomniał, że Wilno w 1553 r. nie posiadało drukarni (wcześniej, w latach 1519-1525, działała w nim oficyna Franciszka Skoryny). W późniejszych latach zostały założone drukarnie protestancka, katolicka i unicka. Wszystkie one odgrywały znaczną rolę przy szerzeniu myśli reformatorskiej oraz kontrreformatorskiej ${ }^{96}$.

Kraszewski podkreśla wielokulturowość miasta, która wynikała choćby z faktu, że swoje świątynie posiadali w Wilnie prócz katolików oraz wyznawców religii prawosławnej także luteranie ${ }^{97}$, cieszący sie protekcją Radziwiłłów kalwiniści ${ }^{98}$, muzułmanie oraz żydzi. Badacz stanowczo stwierdził, że do rozwoju intelektualnego społeczności wileńskiej przyczynili się jezuici, którzy sprowadzeni przez biskupa Waleriana Protasewicza ${ }^{99}$ otworzyli w 1570 r. kolegium, a za sprawą dyplomu erekcyjnego wydanego przez Stefana Batorego przekształcili je w Akademię Societatis Jesu, która stanowiła centrum myśli kontrreformacyjnej ${ }^{100}$.

Wilno, zdaniem Kraszewskiego, w czasach Zygmunta Augusta nie było „drugą stolicą, jak ktoś napisał, ale pierwszą i jedyną"101. Historyk argumentował te słowa faktem, że król często rezydował w Wilnie otoczony licznym dworem oraz urzędnikami zarówno z Korony, jak i Litwy. Rządy ostatniego przedstawiciela $\mathrm{z}$ dynastii Jagiellonów doprowadziły do wzbogacenia miasta i jego mieszkańców ${ }^{102}$. W stolicy osiedlali się rzemieślnicy z Prus i Krakowa, przybywali kupcy niemieccy, tureccy, ruscy. Przy największych traktach ulicznych wznoszone były przez przedstawicieli wielkich rodów litewskich

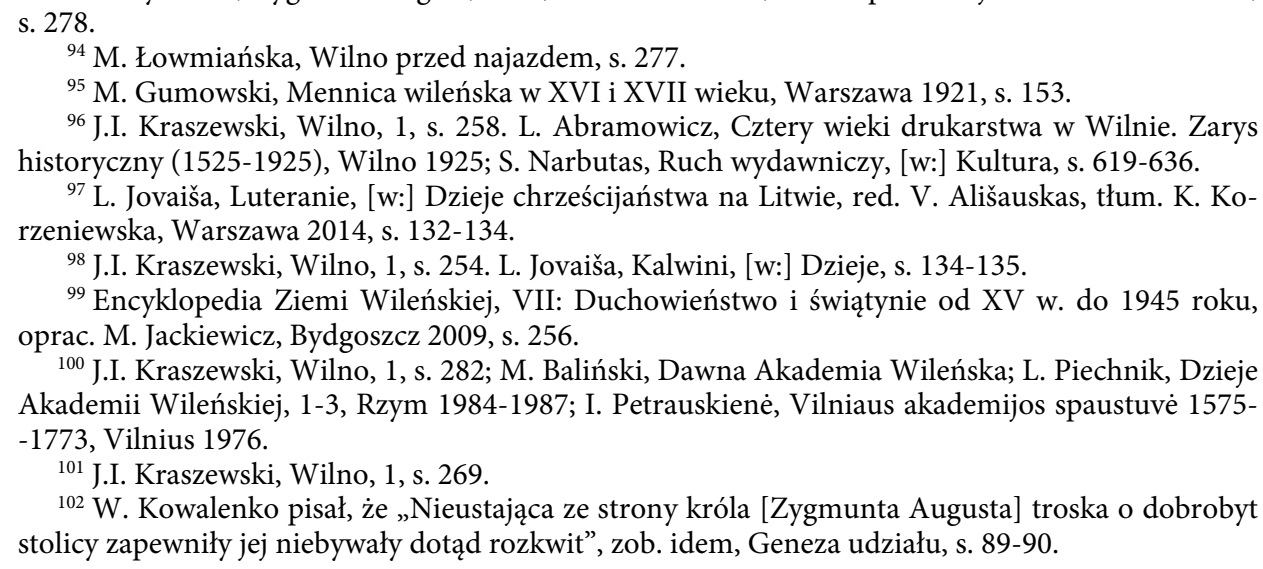

${ }^{94}$ M. Łowmiańska, Wilno przed najazdem, s. 277.

${ }^{95}$ M. Gumowski, Mennica wileńska w XVI i XVII wieku, Warszawa 1921, s. 153.

${ }^{96}$ J.I. Kraszewski, Wilno, 1, s. 258. L. Abramowicz, Cztery wieki drukarstwa w Wilnie. Zarys historyczny (1525-1925), Wilno 1925; S. Narbutas, Ruch wydawniczy, [w:] Kultura, s. 619-636.

${ }^{97}$ L. Jovaiša, Luteranie, [w:] Dzieje chrześcijaństwa na Litwie, red. V. Ališauskas, tłum. K. Korzeniewska, Warszawa 2014, s. 132-134.

${ }^{98}$ J.I. Kraszewski, Wilno, 1, s. 254. L. Jovaiša, Kalwini, [w:] Dzieje, s. 134-135.

${ }^{99}$ Encyklopedia Ziemi Wileńskiej, VII: Duchowieństwo i świątynie od XV w. do 1945 roku, oprac. M. Jackiewicz, Bydgoszcz 2009, s. 256.

${ }^{100}$ J.I. Kraszewski, Wilno, 1, s. 282; M. Baliński, Dawna Akademia Wileńska; L. Piechnik, Dzieje Akademii Wileńskiej, 1-3, Rzym 1984-1987; I. Petrauskienė, Vilniaus akademijos spaustuve 1575-1773, Vilnius 1976.

${ }^{101}$ J.I. Kraszewski, Wilno, 1, s. 269.

${ }^{102}$ W. Kowalenko pisał, że „Nieustająca ze strony króla [Zygmunta Augusta] troska o dobrobyt stolicy zapewniły jej niebywały dotąd rozkwit”, zob. idem, Geneza udziału, s. 89-90.

${ }^{93}$ S. Cynarski, Zygmunt August, s. 47; M. Łowmiańska, Wilno przed najazdem moskiewskim, 
okazałe pałace Radziwiłłów, Chodkiewiczów, Sapiehów, Kiszków, książąt Słuckich oraz Ostrogskich, których fasady w przeciwieństwie do poprzednich wieków zdobiły herby oraz trofea. Podkreślał on, że charakter miastu nadawała przede wszystkim zamieszkująca je zróżnicowana pod względem wyznaniowym i narodowościowym ludność. Historyk zaznaczył, że obraz, który został stworzony „z tylu pierwiastków”, z pewnością wart był rozpatrzenia ${ }^{103}$.

Kraszewski był nie tylko historykiem, ale również malarzem miasta. Patrzył więc na opisywaną rzeczywistość pod kątem jej malowniczości i oryginalności charakteru. Obraz Wilna i jego mieszkańców oddaje zwłaszcza fragment, w którym autor pisał:

W samem mieście nadawała życie liczna i urozmaicona ludność, której ubiory, postaci, język, tysiąc sprzeczności z sobą stawiły i zajmowały oko. Mnichy, żołnierze, kapniki, pachołcy, konie, powozy, lektyki skórzane mieszczan, kolebki złocone panów, mieszały się i mijały. Wspaniałe obrzędy duchowieństwa, poważne uroczystości cechowe, wszystko godne było widzenia, a jeśli temu obrazowi zmuszeni będziem odmówić czystej piękności, niepodobna za to nie widzieć i nie przyznać mu malowniczości i charakteru ${ }^{104}$.

W sposób szczególny podkreślał on również, że stolica W. Ks. Litewskiego znajdowała się na pograniczu Azji i Europy. Dla Kraszewskiego architektura oraz ówczesna panorama miasta była „swoistą księgą dziejów miasta” ${ }^{105}$. Pisał on na kartach swego dzieła:

Powierzchowność miasta nie zawsze znacząca, tu malowała charakter i dzieje mieszkańców; po wieżach Kościelnych, Klasztorach, Cerkwiach i Zborach, można było policzyć wszystkie spory religijne, jakich doznało i doznać miało Wilno; przemagająca liczba duchownych aż nadto pokazywała kto tu był panem. Dumne szable szlachty, szczękające po bruku, jej wozy i kolebki wolne od opłat po bramach i mostach, gdy chłopek musiał nieść pieniądze lub kamień, żeby przejazd okupić, były już oznaką ucisków i przewagi tej uprzywilejowanej części narodu, która od wszystkich ciężarów wolna była $(\ldots)^{106}$.

Wyżej przywołane fragmenty dobrze oddają subiektywny sposób opisu miasta przez Kraszewskiego. Jego spojrzenie na Wilno przez pryzmat histo-

${ }^{103}$ J.I. Kraszewski, Wilno, 1, s. 269.

${ }^{104}$ Ibidem, s. 269-270.

${ }^{105}$ I. Szulska, Inspiracje kulturą Litwy w muzyce i malarstwie, [w:] eadem, Litwa Józefa Ignacego Kraszewskiego, Warszawa 2011, s. 58-62.

${ }^{106}$ J.I. Kraszewski, Wilno, 1, k. 273. 
ryka i literata jednocześnie powoduje, że mamy do czynienia z ujęciem literackim. Warto zauważyć, że dzieła historyczne, ze względu na konieczną faktografię, często pozbawione są tego aspektu ${ }^{107}$.

W czterotomowej historii Wilna Kraszewski podkreśla, że w czasie rządów Zygmunta Augusta stolica Litwy stała się jednym z największych ośrodków miejskich Rzeczpospolitej Obojga Narodów, porównywanym do Krakowa, a może i nawet przewyższającym go. W prezentowanym przez historyka obrazie stanowiła ona $\mathrm{z}$ pewnością centrum życia politycznego, gospodarczego, naukowo-kulturalnego oraz religijnego. Bez wątpienia miasto w tym czasie przeżywało swoją największą świetność. Dzięki spisanym przez Kraszewskiego dziejom Wilna zachowany został obraz miasta, które stanowiło „ukochaną” przez ostatniego Jagiellona siedzibę. Osobiste zapatrywania oraz upodobania Zygmunta Augusta bardzo wyraźnie przekładały się zwłaszcza na tożsamość stolicy W. Ks. Litewskiego (np. tolerancję wyznaniową), miały także swoje odzwierciedlenie w urbanistyce. Należy pamiętać, że w monografii Wilna historyk zawarł również swoje, bardzo malownicze, wyobrażenie o litewskiej stolicy. Obraz ten swą wielobarwność zawdzięcza zwłaszcza autorskiemu subiektywizmowi Kraszewskiego. Wydaje się, że czterotomowe dzieło stanowi hołd złożony miastu. Historyk zadbał, aby przetrwała nie tylko pamięć o Wilnie, ale również o Polsce, która w dobie Jagiellonów była europejską potęga.

\section{Bernadetta Manyś \\ THE "VILNIUS WORLD" OF ZYGMUNT AUGUST \\ IN THE MONOGRAPHY OF THE CITY BY \\ JÓZEF IGNACY KRASZEWSKI}

\section{Summary}

The article sets out to characterise the "Vilnius world" of the last Jagiellon ruler, as presented in the monograph of the Lithuanian capital by Józef Ignacy Kraszewski. Fascinated with Vilnius and its history, the historian devoted a four-volume work to the internal history of the city, also taking into account the context of events concerning the entire country. The scholar stressed the role of the Lithuanian capital and

${ }^{107}$ Problematyka wielorakich interakcji historii i literatury w dorobku J.I. Kraszewskiego szczegółowo została przedstawiona przez Stefana Wrzoska w artykule Klio, siostra Kaliope i Polihymnii. Granice historii i literatury w twórczości J.I. Kraszewskiego i wypowiedziach na jej temat, [w:] B. Czwórnóg-Jadczak (red.), Obrazy kultury polskiej w twórczości Józefa Ignacego Kraszewskiego, Lublin 2004, s. 93-104. 
highlighted its status compared to other major cities. The reign of Zygmunt August was presented in a particularly "picturesque" manner. Therefore this paper attempts to answer the following questions: what kind of an image of Vilnius and its inhabitants in the times of Zygmunt August was presented by Józef Ignacy Kraszewski; how, according to the historian, the presence of the monarch and his court in Vilnius affected the public sphere of life of its inhabitants.

\section{Bibliografia}

Źródła rękopiśmienne

AGAD, Rachunki Królewskie 115, k. 25v-27v.

Opracowania źródłowe

Jagiellonki polskie w XVI wieku, Obrazy rodziny i dworu Zygmunta I. i Zygmunta Augusta Królów Polskich, 1, wyd. A. Przeździecki w Drukarni Uniwersytetu Jagiellońskiego, Kraków 1868.

Kromer M., Mowa na pogrzebie Zygmunta I oraz o pochodzeniu i o dziejach Polaków: księgi XXIX i XXX, Olsztyn 1982.

Zbiór praw y przywilejów miastu stołecznemu W.X.L. Wilnowi nadanych. Na żądanie wielu miast koronnych, jako też Wielkiego Księstwa Litewskiego ułożony y wydany przez Piotra Dubińskiego burmistrza Wileńskiego, W drukarni J. K. Mci przy Akademii, Wilno 1788.

\section{Literatura}

Abramowicz L., Cztery wieki drukarstwa w Wilnie. Zarys historyczny (1525-1925), Nakładem Ludwika Chomińskiego, Polska Drukarnia Nakł. „Lux”, Wilno 1925.

Akty cechów wileńskich 1495-1759, zeb. i oprac. H. Łomiański, wsp. M. Łowmiańska, S. Kościałkowski, przedm. i skorowidze J. Jurkiewicz, Poznań 2006.

Baliński M., Dawna Akademia Wileńska. Próba jej historyi od założenia w roku 1579 do ostatecznego jej przekształcenia w 1803 roku, Nakładem i Drukiem Jozafata Ohryzki, Petersburg 1862.

Baliński M., Historya miasta Wilna, 1-2, Drukiem Antoniego Marcinowskiego, Wilno 1836.

Baliński M., Opisanie statystyczne miasta Wilna, Józef Zawadzki Własnym Nakładem, Wilno 1835.

Baranowski H., wsp. Z. Baranowska, J. Goławska, Bibliografia Wilna, 2: Miasto, Toruń 2000.

Beresnevičiūtè H., J.I. Kraševskis - Lietuvos istorikas, Darbai ir dienos, 1 (10), Kaunas 1995, s. $19-42$.

Bibliografia literatury polskiej „Nowy Korbut”, XII: Józef Ignacy Kraszewski. Zarys bibliograficzny, oprac. S. Stupkiewicz, I. Śliwińska, W. Roszkowska-Sykałowa, Warszawa 1966.

Cynarski S., Zygmunt August, Wrocław 2004.

Dorobisz J., Pobyty Władysława IV Wazy w Wilnie i okolicach, [w:] E. Feliksiak, A. Mironowicz (red.), Wilno i Kresy północno-wschodnie: materiały II Międzynarodowej Konferencji w Białymstoku 14-17 IX 1994 r. w czterech tomach, 1: Historia i ludzkie losy, Białystok 1996, s. 61-74.

Drèma V., Vilniaus bažnyčios. Iš Vlado Drẻmos archyvų, oprac. A. Lèverienè, A. Mickevičius, R. Mosiejienè, Vilnius 2008.

Encyklopedia Ziemi Wileńskiej, VII: Duchowieństwo i świątynie na ziemi wileńskiej od XV w. do 1945 roku, oprac. M. Jackiewicz, Bydgoszcz 2009.

Estreicher K., Bibliografia polska, XII, Kraków 1910.

Ferenc M., Dwór Zygmunta Augusta: organizacja i ludzie, Kraków 1998. 
Fijałek J., Opisy Wilna aż do połowy wieku XVII-go, Ateneum Wileńskie 1, 3-4, 1923, s. 313-336.

Fijałek J., Opisy Wilna aż do połowy wieku XVII-go. Przegląd opisów Wilna od r. 1414 aż do połowy w. XVII-go z uwydatnieniem ich właściwości i wzajemnego do siebie stosunku, Ateneum Wileńskie 2, 1924, s. 122-158, 506-526.

Gołębiowski E., Zygmunt August. Żywot ostatniego z Jagiellonów, Warszawa 1977.

Gumowski M., Mennica wileńska w XVI i XVII wieku, Warszawa 1921.

Janicki M., Janicki M., Górnicki, Kochanowski, Nidecki - wspólne lektury, wzajemne inspiracje? Kilka uwag o środowisku humanistycznym kancelarii Zygmunta Augusta w Wilnie, [w:] P. Salwa (red.), Łukasz Górnicki i jego włoskie inspiracje: materiały z sesji zorganizowanej przez Komisję Dziejów Odrodzenia i Reformacji przy Komitecie Nauk Historycznych PAN (Warszawa, 28-29 listopada 2003), Warszawa 2005, s. 65-84.

Janonienė R., Budownictwo murowane, [w:] V. Ališauskas, L. Jovaiša, M. Paknys, R. Petrauskas, E. Raila (red.), Kultura Wielkiego Księstwa Litewskiego: analizy i obrazy, tłum. P. Bukowiec, B. Kalęba, B. Piasecka, Kraków 2006, s. 114-130.

Jovaiša L., Bractwa, [w:] V. Ališauskas, L. Jovaiša, M. Paknys, R. Petrauskas, E. Raila (red.), Kultura Wielkiego Księstwa Litewskiego: analizy i obrazy, tłum. P. Bukowiec, B. Kalęba, B. Piasecka, Kraków 2006, s. 92-113.

Jovaiša L., Kalwini, [w:] V. Ališauskas (red.), Dzieje chrześcijaństwa na Litwie, tłum. K. Korzeniewska, Warszawa 2014, s. 134-135.

Jovaiša L., Luteranie, [w:] V. Ališauskas (red.), Dzieje chrześcijaństwa na Litwie, tłum. K. Korzeniewska, Warszawa 2014, s. 132-134.

Kaladžinskaitė A., Brolijų dailès užsakymai Vilniuje XVIII a., Dailès istorijos studijos, 2: Dailè LDK miestuose: poreikiai ir užsakymai, Vilniaus dailès akademijos leidykla, Vilnius 2006, s. $145-164$.

Kolankowski L., Zygmunt August Wielki Książę Litwy do roku 1548, Lwów 1913.

Kowalenko W., Geneza udziału stołecznego miasta Wilna w Sejmach Rzplitej, Ateneum Wileńskie 4, 1927, 4, s. 79-137.

Kraszewski J.I., Barbara, [w:] Poezja, 1, Wilno 1838.

Kraszewski J.I., Bekieszówka pod Wilnem. Wyjątek z tomu IV Historii Wilna, Biruta 1838; przedruk: Przyjaciel Ludu 44, 1838-39.

Kraszewski J.I., Pożar zamku wileńskiego 1610. Szkic historyczny, Biruta 1837, s. 169-188 (przedruki tego szkicu oraz opinie o nim opublikowały później Zbieracz Literacki i Polityczny 3, 1837; Tygodnik Petersburski 81-82, 1837; Gazeta Wielkiego Xięstwa Poznańskiego 266,1837$)$.

Kraszewski J.I., Wilno od początków jego do roku 1750, 1, Nakładem i drukiem Józefa Zawadzkiego, Wilno 1840; 2, Wilno 1840; 3, Wilno 1841; 4, Wilno 1842.

Kuchowicz Z., Barbara Radziwiłłówna, Łódź 1976.

Kurczewski J., Biskupstwo wileńskie od jego założenia aż do dni obecnych, zawierające dzieje i pracę biskupów i duchowieństwa diecezji wileńskiej oraz wykaz kościołów, klasztorów, szkół i zakładów dobroczynnych i społecznych, Nakładem i drukiem Józefa Zawadzkiego, Wilno 1912.

Kurczewski J., Kościół Zamkowy, czyli Katedra Wileńska: w jej dziejowym, liturgicznym, architektonicznym i ekonomicznym rozwoju, 1., Nakładem i drukiem Józefa Zawadzkiego, Wilno 1908; 2: Źródła historyczne na podstawie aktów kapitulnych i dokumentów historycznych, Wilno 1910; 3: Streszczenie aktów kapituły wileńskiej, Wilno 1916.

Łowmiańska M., Wilno przed najazdem moskiewskim 1655 roku, [w:] Dwa doktoraty z Uniwersytetu Stefana Batorego w Wilnie, Poznań 2005, s. 151-329.

Marchwińska A., Królewskie dwory żon Zygmunta Augusta: organizacja i składy osobowe, Toruń 2008.

Marchwińska A., Rejestr dworu królowej Barbary (1548-1551), Studia Źródłoznawcze 38, 2000, s. 81-102. 
Maroszek J., Ogrody królewskie w Wilnie i innych rezydencjach Wielkiego Księstwa Litewskiego w XVI wieku, [w:] M. Szafrańska (red.), Królewskie ogrody w Polsce: materiały sesji naukowej, Warszawa, 10-11 maja 2001 roku (The royal gardens in Poland: conference materials, Warsaw), May 10-11, 2001, Warszawa 2001, s. 109-128.

Maroszek J., Wileńskie przytułki - szpitale w XVI-XVIII w., [w:] C. Kuklo (red.), P. Guzowski (wsp.), Cała historia to dzieje ludzi...: studia $\mathrm{z}$ historii społecznej ofiarowane profesorowi Andrzejowi Wyczańskiemu w 80-tą rocznicę urodzin i 55-lecie pracy naukowej, Białystok 2004, s. 191-217.

Narbutas S., Ruch wydawniczy, [w:] V. Ališauskas, L. Jovaiša, M. Paknys, R. Petrauskas, E. Raila (red.), Kultura Wielkiego Księstwa Litewskiego: analizy i obrazy, tłum. P. Bukowiec, B. Kalęba, B. Piasecka, 2006, s. 619-636.

Ochmański J., Biskupstwo wileńskie w średniowieczu. Ustrój i uposażenie, Poznań 1972.

Paknys M., Vilniaus miestas ir miestiečiai 1636 m.: namai, gyventojai, svečiai, Vilniaus dailès akademijos leidykla, Vilnius 2006.

Paszenda J., Wpływ pożarów Wilna na architekturę późnego baroku, [w:] J. Lileyko (red.), Sztuka ziem wschodnich Rzeczypospolitej XVI-XVIII w., Lublin 2000, s. 487-494.

Petrauskienè I., Vilniaus akademijos spaustuvè 1575-1773, Vilnius 1976.

Piechnik L., Dzieje Akademii Wileńskiej, 1-3, Rzym 1984-1987.

Ragauskas A., Vilniaus miesto valdantysis elitas XVII a. antrojoje puseje (1662-1702 m.), Vilnius 2002.

Rożek M., Groby królewskie w Krakowie, Kraków 1977.

Sołtys K., Józef Ignacy Kraszewski jako historyk. Naukowy fundament wykładu dziejów Litwy w monografii Wilna, Warszawa 2013.

Sucheni-Grabowska A., Zygmunt August. Król polski i wielki książę litewski 1520-1562, Kraków 2010.

Szulska I, Inspiracje kulturą Litwy w muzyce i malarstwie, [w:] eadem, Litwa Józefa Ignacego Kraszewskiego, Warszawa 2011 s. 58-62.

Świerzewski S., Józef Ignacy Kraszewski jako historyk Litwy. W setną rocznicę jubileuszu J.I. Kraszewskiego (1879), Kultura i Społeczeństwo XXII, 4, 1978, s. 109-127.

Urzędnicy Wielkiego Księstwa Litewskiego. Spisy, 1: Województwo wileńskie XIV-XVIII wiek, red. A. Rachuba, oprac. H. Lulewicz, A. Rachuba, P.P. Romaniuk; wsp. U. Jemialianczuk, A. Macuk, Warszawa 2004.

Vitkauskiene B.R., Złotnictwo wileńskie: ludzie i dzieła XV-XVIII wiek, Warszawa 2006.

Wojtkowiak Z., Ostrogski Konstanty (ok. 1460-1530), Polski Słownik Biograficzny 24, 3, 1979, s. 486-489.

Wrzosek S., Klio, siostra Kaliope i Polihymnii. Granice historii i literatury w twórczości J.I. Kraszewskiego i wypowiedziach na jej temat, [w:] B. Czwórnóg-Jadczak (red.), Obrazy kultury polskiej w twórczości Józefa Ignacego Kraszewskiego, Lublin 2004, s. 93-104.

Zbiór praw y przywilejów miastu stołecznemu W.X.L. Wilnowi nadanych wielu miast koronnych, jako też Wielkiego Księstwa Litewskiego, wyd. P. Dubiński w drukarni J.K. Mci przy Akademii, Wilno 1788.

Zujienė G., Ceremoniał ingresu biskupów wileńskich w XVII-XVIII wieku, tłum. B. Dwilewicz, Barok. Historia - literatura - sztuka 13/1, 2006, s. 59-77. 